\section{On the Hunting of, and Threats Facing, the Cape Hare (Lepus capensis Linnaeus, 1758) in the Gaza Strip, Palestine}

Abdel Fattah N. Abd Rabou ${ }^{1^{*}}$

\author{
${ }^{1}$ Department of Biology, Faculty of Science, Islamic University of Gaza, \\ Gaza Strip, Palestine \\ * Corresponding author \\ E-mail address: arabou@iugaza.edu.ps
}

https://doi.org/10.33976/IUGNS.29.2/2021/2

\begin{abstract}
:
The Cape Hare (Lepus capensis Linnaeus, 1758) is the only lagomorph in Palestine $\left(27,000 \mathrm{~km}^{2}\right)$. Although it was common in the Gaza Strip 4-5 decades ago, its present occurrence is restricted by several overlapping factors. The current study aims to spotlight the hunting of, and the threats facing, Cape Hares in the Gaza Strip $\left(365 \mathrm{~km}^{2}\right)$. This descriptive study, which lasted 5 years $(2016-2020)$, was based on frequent field visits and observations in addition to meetings and discussions with wildlife hunters and farmers. We found that the eastern parts of the Gaza Strip were the main hunting places for Cape Hares. The methods involved in hare hunting included shooting, foothold traps, live traps known locally as "Maltash", net walls, pit traps and coursing which involves the use of greyhounds. Wildlife hunters described the hunting of Cape Hares as a complicated task due to its low occurrence, extreme caution, difficulty of tracking it, presence near the Israeli security fence, which poses a danger to hunters, in addition to the great experience and high concentration that such hunting requires. Cape Hares face several threats, some of which are Israeli, and some specific to Gazans and the environment of the Gaza Strip. The Israeli threats include the Israeli security fence which prevents the natural flow of wildlife between the Gaza Strip and the rest of the Palestinian territories, Israeli wars and invasions, and the Israeli spraying of herbicides at the eastern border areas of the Gaza Strip for claimed security reasons which eradicates the plant cover supporting hares and other fauna with shelter and food. The Gazan threats include urban encroachment at the expense of natural habitats, excessive use of chemical pesticides, overhunting of Cape Hares, noticeable increase of opportunistic carnivores feeding on Cape Hares, and weakness of environmental awareness campaigns and laws that protect wildlife. Finally, the study recommends the use of all possible means to sustainably protect and conserve wildlife including Cape Hares in the Gaza Strip.
\end{abstract}

\section{Keywords:}

Cape Hares, Lepus capensis, wildlife hunters, hunting, threats, pesticides, Gaza Strip. 


\section{Introduction:}

In spite of its small area $\left(27,000 \mathrm{~km}^{2}\right)$, Palestine is home to more than 100 species of wild mammals occurring in different environments. Such mammalian diversity comes as a reflection of the geographic position of the country at the meeting point of the three continents: Asia, Africa and Europe and the three zoogeographical areas: Palaearctic, Afrotropical, and Oriental (Qumsiyeh, 1996). The diversity of the country's landscapes, ecosystems, habitats and niches promotes mammalian fauna species diversity (Qumsiyeh, 1996; Abd Rabou, 2005 and Albaba, 2016). Hares (Lepus spp.) are widely distributed across the globe and are adapted to diverse climatic conditions. They are common in all Middle East countries as well (Harrison and Bates, 1991; Al-Jumaily, 1998; Basuouny, 1998; Bunaian et al., 2002; Hoath, 2003; Dolev and Perevolotsky, 2005; De Marimis and Masseti, 2009; Amr, 2012; Moores et al., 2012; Al-Sheikhly et al., 2015; Essghaier et al., 2015; Edwards et al., 2017; Paray and Al-Sadoon, 2018; Bsissa et al., 2019; Meiri et al., 2019 and Yusefi et al., 2019) including Palestine (Qumsiyeh, 1996). According to King (1990), hares are similar in appearance to rabbits but can be distinguished by their larger size, proportionally larger hind legs, more rakish build, richer tawny color, black-tipped ears and their characteristic loping, tail-down gait when disturbed. The Cape, Desert, or Arabian Hare (Lepus capensis Linnaeus, 1758) is a mammalian species belonging to Leporidae family and Lagomorpha order (Boitani and Bartoli, 1983). The Cape Hare inhabits grasslands, deserts, semi-deserts and sand dunes (Boitani and Bartoli, 1983; Harrison and Bates, 1991; Qumsiyeh, 1996; Hoath, 2003). It is the only lagomorph in the Palestinian Territories. It lives in a variety of ecosystems and habitats such as deserts including the Negev Desert in southern Palestine, mountainous and rocky regions characterizing the West Bank, forests, dense wooded areas, grasslands, sand dunes and near rivers, streams and wadis (valleys) (Kronfeld and Shkolnik, 1996; Qumsiyeh, 1996; Abd Rabou, 2005, 2011 and 2019a; Yassin et al., 2006 and Abd Rabou et al., 2007a).

Work on several aspects targeting the ecology, biology, physiology and even behavior of Hares including the Cape Hare seems to be extensive worldwide (Frager, 1977; Flux and Flux, 1983; Robinson and Dippenear, 1983; Tapper and Barnes, 1986; Kronfeld and Shkolnik, 1996; Edwards et al., 2000; Smith et al., 2004; Panek et al., 2006; Reichlin et al., 2006; Suchentrunk et al., 2006 and 2007; Kamler, 2007; Kamler et al., 2008; Zellweger-Fischer et al., 2011; Demirbaş et al., 2013; Djan et al., 2017; Lado et al., 2019; Schai-Braun et al., 2019; Sliwinski et al., 2019 and Zaman et al., 2020). The Cape Hare (Lepus capensis Linnaeus, 1758) seems to be the commonest among other hare and rabbit species in the Arab and the Middle East countries of both Africa and Asia as a lot of mammalian guidebooks pointed out (Boitani and Bartoli, 1983; Flux and Flux, 1983; Amr and Disi, 1988; Harrison and Bates, 1991; Haltenorth and Diller, 1996; Qumsiyeh, 1996; Al-Jumaily, 1998; Amr, 2000 and 2012; Hoath, 2003; Amr et al., 1987 and 2004; Wilson and Reeder, 2005; Meiri et al., 2019; Eid, 2018 and Eid et al., 2020).

Studies of the Cape Hare in the Arab and Middle East countries were found to be escalating, covering aspects of their taxonomy, biology, ecology and ethology. In Israel, Yom-Tov and Yom-Tov (2012) studied the temporal changes in skull size of samples of mammalian fauna, including the Cape Hare (Lepus capensis) collected during the 20th Century in Israel. Moran (1981), Moran and Keidar (1993) and Meiri et al. (2019) surveyed the animals causing harm to agriculture in Israel, of which the Cape Hare was a clear example. In the United Arab Emirates (UAE), Drew (2000) surveyed the distribution of Cape Hares throughout the Emirate of Abu Dhabi. He found that the distribution was patchy and appeared to be affected by the level of grazing by domesticated animals and by anthropogenic disturbance. In Sudan, Mohammed et al. (2010) made morphometric studies on the skulls of different hares collected from different parts of the country. In Libya, Essghaier et al. (2015) and Elkahwage and Jdeidi (2018) surveyed the mammalian fauna including hares in different ecosystems and protected areas. In southern Tunisia, Chammem et al. (2017) estimated Cape Hare occupancy and abundance using spotlighting data. Mohsen et al. (2017) studied the spatial 
occupancy of the Cape Hare over southern Tunisia and revealed a positive relationship between its occurrence and the availability of Poaceae and Plantaginaceae. Moreover, Ben Sliman et al (2005 and 2008a and b) studied the biochemical and population genetics of many hare species with particular emphasis on the Cape Hare. In Turkey, Oğurlu (1997) studied habitat use and food habits of the Brown Hare (Lepus europaeus) in a woodland. Sert et al (2005) concentrated their study on the genetic diversity of the Brown Hare in Anatolia, Turkey.

Specific studies on the biology and ecology of the Cape Hare in the Palestinian Territories (West Bank and Gaza Strip) seem to be lacking. Cape Hares were surveyed among the vertebrate fauna prevailing in certain ecosystems of the Palestinian Territories (West Bank and Gaza Strip). In the West Bank, various ecological surveys revealed the Cape Hare as the only lagomorph, occurring in multiple ecosystems and habitats. Khalaf (1983) listed four races or subspecies of the Cape Hare occurring in the Palestine environment: Lepus capensis syriacus, L. C. sinaiticus, L. C. arabicus and L. C. cheesmain. Of these races, L. c. syriacus is the commonest. Anabtawi (2011) summarized the hazards facing wildlife in the West Bank with particular emphasis on Cape Hares. Albaba (2016) revealed the presence of 65 mammalian species in the Palestinian Territories, with the Cape Hare was the only lagomorph. Albaba (2017) found specimens of the Cape Hare among the roadkills of the West Bank governorates. Qumsiyeh et al. (2014) revealed significant declines in vertebrate fauna, of which the Cape Hare was a part, in the area of the Bethlehem governorate of the West Bank, which has increasingly become urbanized, with an increase in temperature and a decrease in annual rainfall over the past four decades. Moreover, Qumsiyeh (2016) described the Cape Hare as one of 19 mammalian species occurring in Wadi Al-Quff Protected Area, which is located in northern Hebron. This area is considered one of the ecologically important areas needing urgent biodiversity conservation measures (Qumsiyeh et al., 2016). The Apartheid Wall that Israel built nearly two decades ago contributed to lack of biodiversity flow between the West Bank and the rest of the occupied Palestinian Territories in 1948. Accordingly, large and medium-sized land mammals, including the Cape Hare, are among the most affected forms of wildlife (Abdallah and Swaileh, 2011).

As far as the Gaza Strip is concerned, several vertebrate faunistic studies revealed the occurrence of the Cape Hare in multiple ecosystems as well. MedWetCoast (2002), Abd Rabou (2005 and 2011a) and Abd Rabou et al. (2007) recorded the Cape Hare as one of the mammalian fauna of Wadi Gaza Nature Reserve in the middle of the Gaza Strip. Yassin et al. (2006) and Abd Rabou (2019a) encountered the species in both the northern and southern parts of the Gaza Strip. A single caged specimen of the species was encountered at Gaza zoos as well (Abd Rabou, 2011b). In spite of this widespread occurrence, no specimens of it were preserved at the biological exhibitions of local universities. Such a situation was attributed to the fact that the Cape Hare has become a rare mammal in the Gaza Strip, and all hunted specimens go for food purposes (Abd Rabou, 2020a and Abd Rabou et al., 2020). The Cape Hare as mentioned to be one of the biological threats facing the archaeological sites and buildings in the Gaza Strip because the burrows it digs in the ground may cause the demolition of some ancient parts (Abd Rabou, 2019b). Analogous to the Israeli Apartheid Wall in the West Bank (Abdallah and Swaileh, 2011), the barbed metal fences built by Israel to isolate the Gaza Strip from the rest of the occupied Palestinian Territories in 1948 constitute an obstacle to the flow of biodiversity; no doubt large and medium-sized mammals, of which the Cape Hare is a part, are the most affected, as indicated by UNEP (2003), Abd Rabou et al. (2007a) and Abd Rabou (2009a). The hunting activities of the Palestinians exerted on the Cape Hare have never been studied in the Gaza Strip or the West Bank. The current study aims to spotlight hunting of the Cape Hare (Lepus capensis Linnaeus, 1758) in the Gaza Strip - Palestine. The importance of this study is due to the fact that its modest results may motivate the relevant environmental authorities to find ways to protect the Cape Hare and its dwindling populations in a sustainable manner. 


\section{Materials and Methods:}

\subsection{Gaza Strip}

The Gaza Strip $\left(365 \mathrm{~km}^{2}\right)$ is a coastal zone lying in the southern part of the Palestinian coast along the eastern shore of the Mediterranean basin (Figure 1). It is surrounded by the occupied Palestinian Territories from the east and north, Egypt to the south and the Mediterranean to the west. It is composed of five governorates: North Gaza, Gaza, Middle, Khan Younis, and Rafah. The Gaza Strip has a population of about 2.25 million, mostly refugees from the 1948 Nakba. The population density is about 5,500 inhabitants per square kilometer, making the Gaza Strip one of the most densely populated areas in the world (UNEP, 2003). The Gaza Strip is characterized by its semi-dry Mediterranean climate, which is hot in summer and cold in winter. The average temperatures in the Gaza Strip range from $25^{\circ} \mathrm{C}$ in summer to $13^{\circ} \mathrm{C}$ in winter. The average annual rainfall is $300 \mathrm{~mm}$. The daily relative humidity fluctuates between $65 \%$ and $85 \%$ in summer and between $60 \%$ and $80 \%$ in winter. Sand dunes are the main feature of the western part of the Gaza Strip, while the clay and clayey lands predominate in the eastern part (UNEP, 2003).

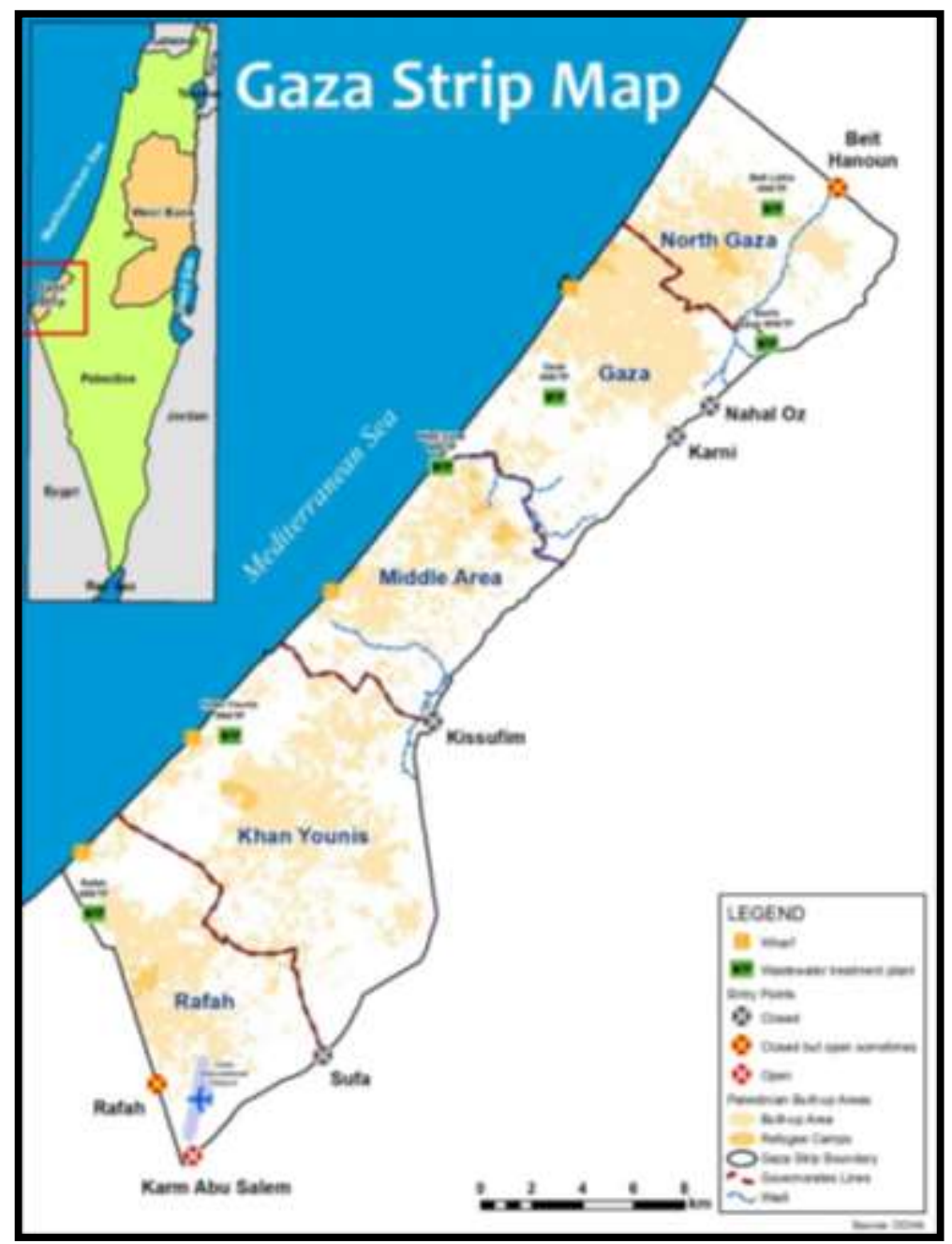

Figure 1 A map showing the geographic position of the Gaza Strip 


\subsection{Procedure}

The current descriptive study, which lasted 5 years (2016 - 2020) was based on frequent field visits and direct observations to various ecosystems within the limits of the Gaza Strip. Most visits were carried out in the early or late hours of the day which are the favorite times for wildlife hunting activities in the Gaza Strip. Particular emphasis was paid to the eastern belt of the Gaza Strip near the political borders with Israel because of its specialty in harboring many opportunist and breeding mammalian species including the Cape Hare; the core of the current study. This eastern belt of the Gaza Strip is characterized by its richness in cereal, vegetable and fruit production in addition to the presence of a lot of animal husbandry and poultry. Frequent meetings and discussions with wildlife hunters, and local farmers were carried out to get more information and to close the gaps regarding the occurrence and hunting of the Cape Hare in the Gaza Strip. Finally, the use of professional binoculars and digital cameras was of a priority throughout the succeeding stages of the current study for documentary and confirmatory purposes.

\section{Results}

\subsection{Description of Local Cape Hares}

The Cape, Desert or Arabian Hare (Lepus capensis Linnaeus, 1758) is characterized by having welldeveloped legs for leaping and running, and large eyes and ears that protect it from the threats and enemies found in its open surroundings. The eyes are often surrounded by a white ring. The soft coat of the species varies in color from light brown to reddish. As a sexual dimorphism character, females of Cape Hares are usually larger than males (Figure 2).

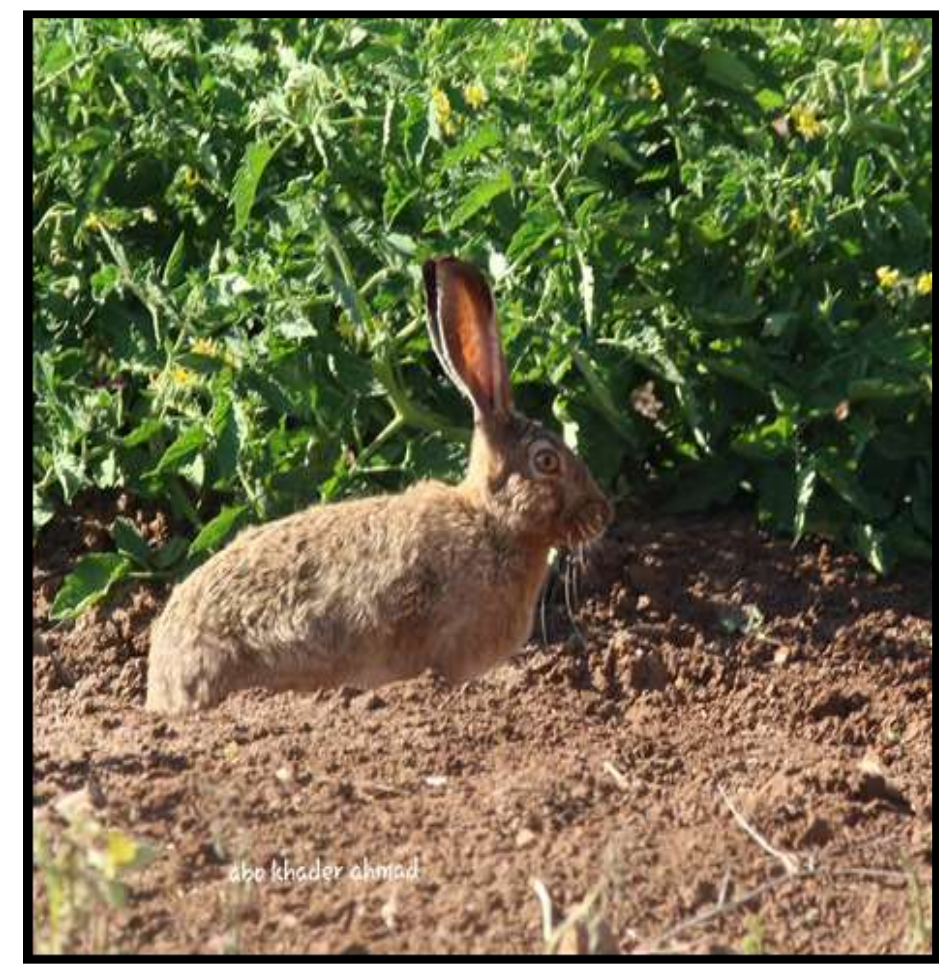

Figure 2 The Cape Hare (Lepus capensis Linnaeus, 1758) is a common mammalian species of the Palestine environment [Photo taken by Ahmed K. Jbareen, 2020] 


\subsection{Local Hunting of Cape Hares}

In the morning, many wildlife hunters target the eastern and northern parts of the Gaza Strip to pursue their hobby of hunting wildlife including Cape Hares that they inherited from their parents. Some bring the hunting pressure cookers, coffee and tea, salt, spices and barbecue skewers, to cook and grill in the natural environment. Hunters usually describe the meat of the Cape Hare as delicious, far better than that of Domestic or Pet Rabbits (Oryctolagus cuniculus domesticus), which many families in the Gaza Strip raise indoors and in their barns. Gazan hunters usually hunt the Cape Hare for its delicious meat, not for sustenance or sale. A hunter says: "We did not sell what we hunt in our lives, and this is what we learned from our elders, from whom we inherited the hobby of hunting". As well as hunting for meat, a few Gazans may hunt Cape Hares for sport or to gain fur as a decoration item or as a way to brag that he's a good hunter.

\subsection{Methods of Cape Hare Hunting}

Many wildlife hunters recalled their participation 20 - 30 years ago in Cape Hare hunting activities in the green and sandy areas near the "Netzarim" and the "Gush Qatif" Israeli settlement in the middle and south of the Gaza Strip. At that time, Cape Hares were abundant over most wild and agricultural areas of the Gaza Strip. Field inspections and interviews with wildlife hunters showed many of the hunting methods used in poaching, chasing and hunting Cape Hares in the Gaza Strip. After capturing Cape Hares, hunters slaughtered them and prepared them for barbecue in the open or at home. Hunters described the taste of the flesh of Cape Hares as delicious because they were reared in the wild. The common methods of hunting Cape Hares and other mammalian fauna are:

1. Hunting Hares with guns or rifles: Shooting with a gun (khartoush) or rifle (Bondokia or Baroud) is one of the most common wildlife hunting methods in the Gaza Strip (Figure 3). With or without dogs, Gazans usually hunt Cape Hares in the early morning or just before sunset, while wandering through fields, orchards, scrub, sand dunes and other ecosystems. The ease of hunting hares with guns comes from the fact that hares seldom leave the area in which they live, and even if they flee from the place they will eventually return to it.

2. Foothold traps with metal jaws: The Gazans use foothold or leghold traps (Kamasha) to hunt Cape Hares in addition to other larger and medium-sized land mammals such as Red Foxes, Golden Jackals, Jungle Cats, Egyptian Mongooses and many others that may cause harm to humans, their property, farms and domestic animals (Figure 4). The danger of these traps lies in their metal jaws, which usually cause pain or breakage in the limbs of the hunted animals. Many of these affected animals have been seen in the field or in the zoological gardens (zoos) prevailing in the governorates of the Gaza strip and most of them were carnivores belonging to order Carnivora.

3. Erection of net walls: This hunting mechanism is commonly achieved by erecting a circular wall of nets around agricultural lands or bushes that house hares or burrows where hares live and hide. Making a noise causes Cape Hares to get out of their hiding places and fall into the net.

4. Live traps known locally as "Maltash": Live traps are wire cages of different shapes, colors and sizes that are manufactured locally and equipped with a trigger plate attached to the entrance. As soon as the Cape Hare passes over it and enters the cage, the entrance is closed (Figure 5). After baiting, the cage is placed where the hare is more active, as inferred from the excrement that it leaves behind. It is preferable to test the live trap frequently to make sure that it works well. It is recommended to camouflage the trap with some plant materials like branches and leaves. 


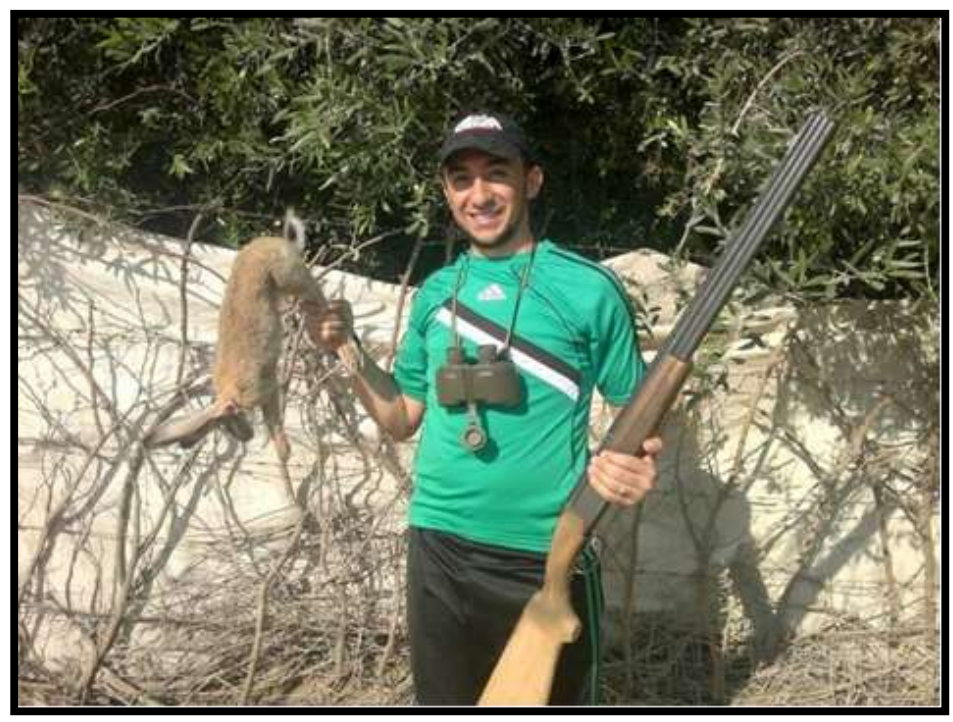

Figure 3 Hunting Cape Hares with guns or rifles in the Gaza Strip

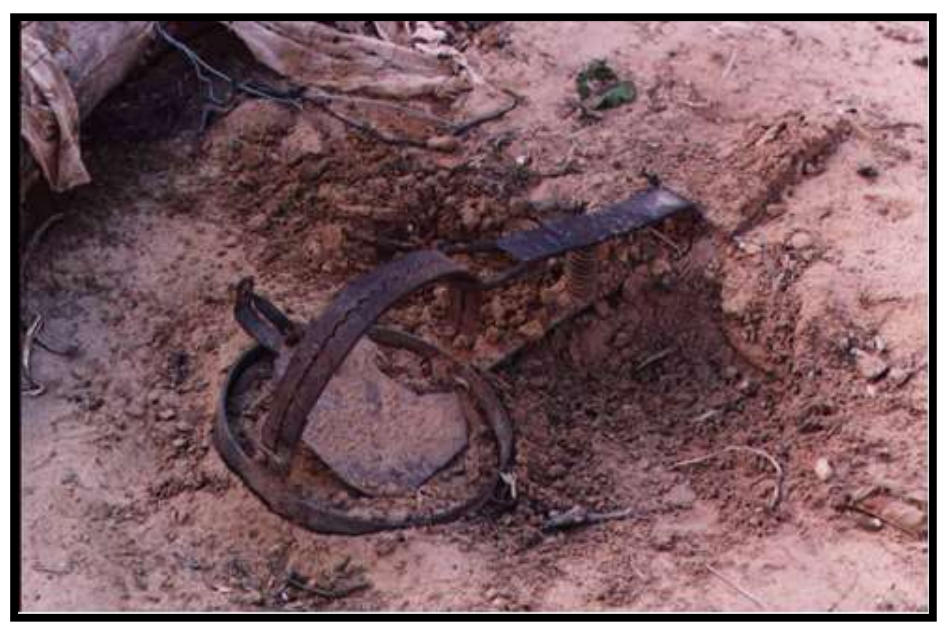

Figure 4 Foothold traps with metal jaws are sometimes used to catch Cape Hares and other carnivore species in the Gaza Strip.

5. Pit traps: Cape Hares and other wildlife species can be caught with pit traps. In areas marked by the presence of hares, some hunters dig a narrow hole or pit of more than 1.5 meter deep, to prevent the hare jumping out. The pit can be camouflaged by covering it with a sufficient amount of twigs, branches and leaves. Suitable baits can be placed over the pits to attract the hare. Pit traps should be checked frequently because hares or any other animal may be stuck in the pit. To avoid being bitten while trying to remove animals other than hares, gloves are recommended, especially if the trapped animal is expected to have diseases such as rabies.

6. Hunting Hares with Greyhounds: Coursing is the sport of hunting rabbits and hares using dogs to track or chase the prey. Although it seems to be very rare in the Gaza Strip, a few Gazans claimed that some amateurs used the greyhound and other dog breeds in hare hunting for both sport and meat purposes. Such claims of rabbiting need verification in the Gaza Strip, although the use of greyhounds is very common in countries with vast areas and with plenty of hares. 


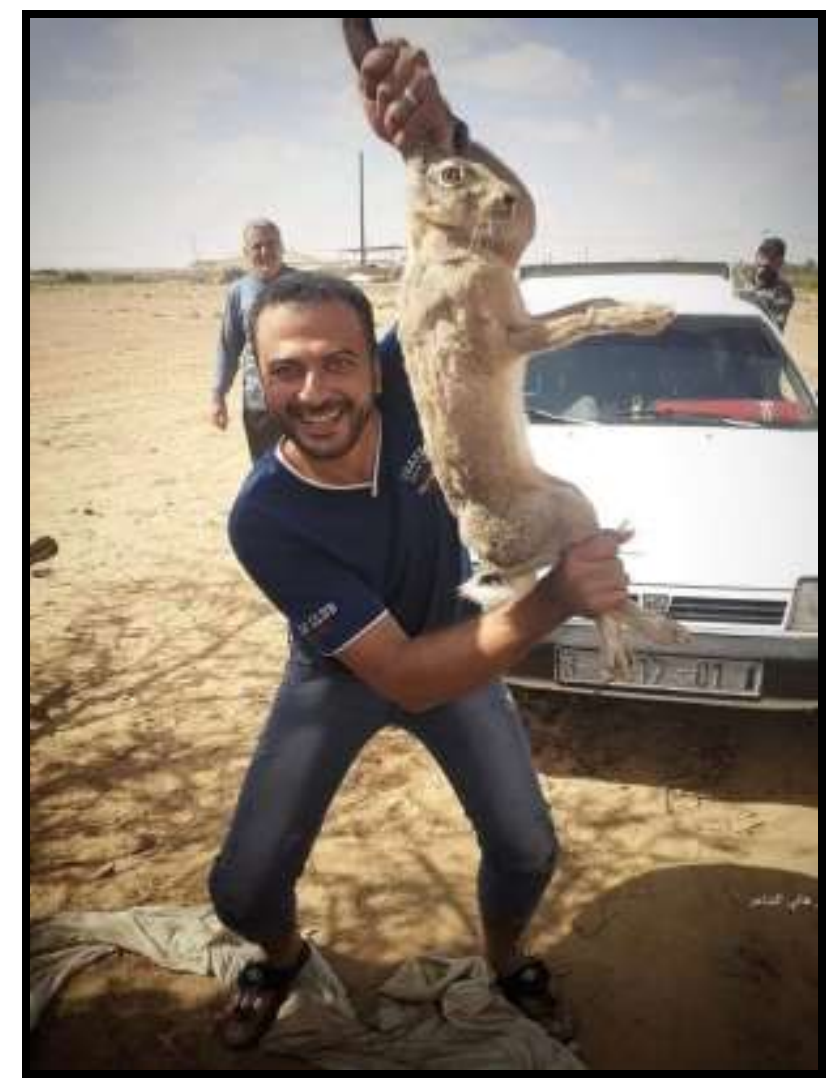

Figure 5 Palestinians trapping a Cape Hare using live traps (Maltash) in Khan Younis, southern Gaza Strip

\subsection{Why Hunting Cape Hares is Valued?}

Hunting Cape Hares is not an easy task in the Gaza Strip, an area characterized by its environmental injustice, political instability, Israeli blockade imposed on it since 2006, and high rates of poverty and unemployment. Wildlife hunters enjoy hunting Cape Hares for the following reasons:

1. The numbers of Cape Hares are few and very rare in the Gaza Strip environment. Residential growth and urban encroachment at the expense of natural environment in the Gaza Strip, which is accompanied with infrastructure development and destruction of ecological habitats, is a crucial factor in lowering the extant numbers of Cape Hares. Also, Gazans believe that the Israeli bulldozing operations on the borders and the erection of more earth mounds and barbed wire are crucial reasons for lowering the numbers of hares in the Gaza Strip. In comparison, the numbers of Cape Hares are abundant inside the occupied Palestinian Territories and multiply there constantly.

2. The search for a Cape Hare may extend for several days nowadays. Wildlife hunters carefully search sand dunes for the footprints of the Cape Hare, and after making sure that it is in the place, they make a noise to push it out of its hiding place and shoot it with a shotgun. More than 3-4 decades ago, some wildlife hunters could hunt 10 hares per day, but now the hunter may stay for days until he catches one hare.

3. Hunting of Cape Hares often takes place near the political wire fences separating the Gaza Strip from the rest of the Palestinian lands occupied by Israel in 1948. Such hunting puts the lives of wildlife hunters at risk if they try to go there because of security and military measures 
taken by the Israel army. It is worth mentioning that many bird hunters have been killed or harmed by the Israeli soldiers while practicing wildlife hunting.

4. The process of hunting Cape Hares in the Gaza Strip is said by hunters to be very difficult and needs great experience and high concentration, due to its high speed, and because it is a cautious animal and often escapes at the last moment.

\subsection{Threats Facing Cape Hares in the Gaza Strip}

As far as the threats facing the Cape Hare in the Gaza Strip are concerned, they are so many. Some are Israeli, while the others are specific to Gazans and the environment of the Gaza Strip:

1. The political wire fences separating the Gaza Strip from the rest of the Palestinian lands occupied by Israel in 1948, and from Egypt as well. These measures negatively impact the natural movement of vertebrate fauna including the Cape Hare. They impede the normal ability of animals to move from one place to another.

2. The Israeli construction of barriers and dams that prevent the natural flow of surface water coming from the Hebron mountains and the Negev desert through the valleys to the Gaza Strip, thus reducing the amount of groundwater resulting in scarcity, pollution and mismanagement. The abundance of water in the various ecosystems, including the wadis of the Gaza Strip, contributes to the growth of vegetation cover, which in turn supports animal life in its various forms and species, including the Cape Hare.

3. The urban encroachment which characterizes the Gaza Strip at the expense of natural environment. Such encroachment promotes habitat loss in terms by habitat destruction, modification and fragmentation, which in turn lowers the occurrence of faunistic species and threatens their populations, with the Cape Hare just another example.

4. The repeated Israeli wars and invasions have caused tremendous destruction of the entire fragile environment in the Gaza Strip, which affects the agricultural, floral and faunal diversity. The Cape Hare is not exempt from these effects. The Israeli operations in the Gaza Strip usually include the leveling of agricultural and natural lands, especially those in the eastern areas of the Gaza Strip, which are considered one of the most important ecological habitats for the Cape Hare. The use of heavy military equipment and lethal weapons, including internationally banned weapons, contributes to the destruction of all aspects of the Gaza environment and its biodiversity.

5. The Israeli use of aircrafts to spray border areas of the eastern Gaza Strip with various chemical pesticides, especially herbicides and germination inhibitors of unknown effects and risks, destroy the wild and agricultural vegetation cover. This eliminates the animal diversity that depends on it, including the Cape Hare that feeds on a variety of plants.

6. The extensive and intensive application and use of agrochemicals, which include chemical pesticides and fertilizers, in the Gaza Strip. Some of these agrochemicals may be dangerous and persistent in nature and do not degrade easily in the environment, and others may be prohibited, carcinogenic, or mutagenic, which often enter the Gaza Strip illegally.

7. Overhunting practices of the Gazans to terrestrial biota using all hunting means especially the indiscriminate ones. It is worth mentioning that overhunting increased after 1994 as a result of the facilities provided by the Palestinian National Authority to weapons purchasers and the ability to license them without restrictions. 
8. The significant increase in the number of carnivores that followed the Israeli withdrawal from the Gaza Strip in late 2005 may constitute a reason for the dearth of hare populations in the Gaza Strip. Many Gazan farmers and poultry pens owners suffered from the occurrence and possible reproduction of the Red Fox, Golden Jackal and Gray Wolf in the Gaza Strip in the last couples of years, which may predate on Cape Hares as one of their food items.

9. Weakness of environmental and ecological awareness among Gazans due to the lack of programs aimed at raising awareness towards wildlife knowledge and conservation in Palestine. The problems of poverty and unemployment aggravate environmental injury: how can a person without food and clothing be expected to pay attention to aspects of the environment and its protection?

10. Weakness of environmental legislations and laws that control wildlife hunting and the damage imposed by local people on ecological habitats, especially the keystone ones that harbor threatened wildlife species.

\subsection{How to Conserve Cape Hare Populations?}

Generally speaking, all wildlife species suffer from the fragility of the Gaza Strip ecosystem. Sensitive wildlife species face a variety of overlapping threats, and urgent solutions should be adopted to lower their impacts:

1. The application of environmental legislations and laws to protect wildlife; particularly the low population of the Cape Hare.

2. The provision of ecological awareness and extension campaigns by specialized environmental and biological teams in the Gaza Strip. Such activities should be financially supported to achieve positive results.

3. The use of social media is a cheap method that could be used by responsible authorities to protect wildlife. In fact, biodiversity conservation is a moral and religious duty that the Palestinians must be proud of, especially as they live in an occupied country suffering from environmental and political injustice imposed by the Israeli occupation since 1948.

\section{DISCUSSION}

Palestine is home to more than 100 mammalian species, but the order Lagomorpha is represented by only one species; the Cape Hare (Lepus capensis Linnaeus, 1758) with four races (Khalaf, 1983 and Qumsiyeh, 1996). The same hare is prevalent in the Palestine's neighboring countries such as Egypt, Lebanon and Jordan in addition to other Middle East countries (Seddon et al., 1997; Amr, 2000 and 2012; Hoath, 2003; Nader et al., 2011 and Elkahwage and Jdeidi, 2018). The harsh and fragile environment of the Gaza Strip seems to harbor low populations of mammalian fauna like carnivores, insectivores, artiodactyls, and the currently studied lagomorphs (MedWetCoast, 2002; Abd Rabou et al,, 2007a; Abd Rabou, 2005; 2009a; 2011a; 2019a). The exceptions are the Egyptian Mongoose (Herpestes ichneumon), rodents and bats, which are present in reasonable populations (Abd Rabou, 2019a and c). Some of them are considered pests by the Gazans because they pose a threat to crops and domestic animals (MedWetCoast, 2002; Abd Rabou et al., 2007a and Abd Rabou, 2019c). The Cape Hare, which is respected locally for its delicious meat, is also considered a pest that damages agricultural crops (Brooks et al., 1988; Moran and Keidar, 1993; Moran 2003 and Strevens and Rochford, 2004). The benefits of the genus Lepus come from the fact that hares constitute the base of many predator-prey interactions. Moreover, hares constitute a major human food resource, model laboratory animals, valued game and provide scientific insights into entire trophic systems. In 
this regard, the Cape Hare has never been used for dissection purposes because of its rarity in the local environment. Instead, the Domestic Rabbit (Oryctolagus cuniculus) is used in dissection lessons as well as in experimental biological and medical research in the Palestinian universities. As far as the meat of the Cape Hare is concerned, Gazans seem to be fond of its taste, especially when cooked al fresco. Experiments on the chemical composition of the meat of the South African Springhare (Pedetes capensis) demonstrated that it has a high protein content $(\sim 22.5 \mathrm{~g} / 100 \mathrm{~g}$ meat $)$ and low lipid (less than $1.3 \mathrm{~g} / 100 \mathrm{~g}$ meat) content. At the same time, the meat of this rodent was found to be comparable to that of commercially reared rabbits (Erasmus and Hoffman, 2020). From a medical point of view, Aloufi and Eid (2016) pointed out that the flesh of the Cape Hare was used in Jordan and Saudi Arabia to treat bronchial asthma.

Wildlife hunting was and is still a common phenomenon in the Gaza Strip. The majority of terrestrial wildlife is subject to hunting and trapping for different purposes as pointed out in many local studies (Abd Rabou, 2005, 2009a, 2011a and b and 2019a and Abd Rabou et al., 2007a). Many factors promoted such hunting including poverty, unemployment, low socioeconomic standards (Abd Rabou, 2009b) and weakness of both ecological awareness and environmental laws (Abd Rabou et al., 2007a). Although hunting is common in all ecosystems and habitats of the Gaza Strip, it is mostly practiced in the eastern parts near the borders separating it from the rest of the Palestinian lands occupied in 1948. This is simply because most common and even rare wildlife species occur there. Opportunist mammals such as carnivores and artiodactyls were known to enter the Gaza Strip, through some gates, gaps or underground burrows, coming from the rest of the Palestinian Territories towards the Gaza Strip (Abd Rabou, 2009a). The concentration of agriculture, poultry farms, solid waste land fills and the newly constructed wastewater treatment plants in the eastern part of the Gaza Strip attracts such wildlife richness and flow from east to west (Abd Rabou et al., 2021). Nocturnal species feed on both wild and domestic animals and even fruits and vegetables when the eastern regions of the Gaza Strip are enjoying complete calm due to the departure of farmers to their relatively remote homes, and because of the military and security measures and risks imposed by Israel at the edges (Abd Rabou, 2019c and Abd Rabou et al, 2021). It should be noted here that a number of wildlife hunters have been killed while practicing their hobbies in these relatively pristine areas (Abd Rabou, 2005). From an ecological point of view, the relatively bigger home ranges of large and medium-sized mammals inhabiting the scrub, agricultural lands and the Negev Desert of southern Palestine make some of them cross borders towards the Gaza Strip (Reuven, and Geffen, 1999; Abd Rabou, 2009a and Afik and Alkon, 2013). Although the Cape Hare breeds in the Gaza Strip, some may enter as opportunists in the eastern parts of the Gaza Strip as claimed by local farmers and wildlife hunters.

Methods of hunting means of Cape Hares are diverse as the current findings showed. Shooting by guns and rifles seemed to be the commonest way, as for most wildlife species of the Gaza Strip (Figure 3). Similar results concerning the use of shooting to hunt wildlife were very common in the region; especially in Egypt and Jordan, close neighboring countries to Palestine (Elhalawani, 2016; Qumsiyeh et al., 2016; Eid, 2018; Eid and Handal, 2018 and Eid et al., 2020). A study in Jordan by Eid and Handal (2018) showed more than 400 hare specimens killed by Jordanian hunters were posted on Facebook in 2015. The majority of footholds traps with metal jaws used in capturing the mammals of the Gaza Strip were manufactured locally by clever hunters. The metal jaws harm the animals hunted. Some wildlife hunters, including hare hunters, confirmed injuries or loss of limbs and possibly death of animals that were caught by foothold traps. In 2008, the author saw a caged Red Fox (Vulpes vulpes) in Rafah zoo with a leg missing because it was caught in a foothold trap (Abd Rabou et al., 2021). To overcome this danger, many countries now cover the jaws with safe rubber cushions to prevent suffering or fracture of the limbs (Philip et al., 1996). The live trap, which is known locally as "maltash" is a common trap type in the Gaza Strip. Hares and most carnivores (Abd Rabou et al., 2007a; Abd Rabou, 2009a and 2019c) have been trapped in this way using baits or lures. In the eastern parts of the Gaza Strip, the Egyptian Mongoose (Herpestes ichneumon) has been 
commonly trapped in this way by farmers to combat its frequent attacks on poultry (Abd Rabou, 2019c). This trapping means is very safe in the sense that no lesions can occur to trapped animals. In the Sudan, the author used this method to hunt the African Civet (Civettictis civetta) along the River Nile in the Khartoum State in 1994 to investigate its possible role in the transmission of leishmanesis. Moreover, the same method was used by the author to trap the Agag Gerbil (Gerbillus agag) in sesame fields in the Kordofan State of the Sudan.

In the Gaza Strip, live traps of various sizes and shapes have been locally manufactured and commonly applied to trap various rodent species living in the wild, agricultural lands and even human dwellings. The Ship or Black Rat (Rattus rattus), Norway or Brown Rat (Rattus norvegicus), House Mouse (Mus musculus), Greater Egyptian Gerbil (Gerbillus pyramidis) and Lesser Egyptian Jerboa (Jaculus jaculus) are common rodent species trapped in various ecosystems within the Gaza Strip for both control and scientific purposes as pointed out by Abd Rabou et al. (2007a) and Abd Rabou (2019a and c). Such traps are commonly used in studies dealing with small and medium-sized mammals (Shilereyo et al., 2020). Pit traps were rarely used in the Gaza Strip, especially in its western belt which is characterized by its sand dunes topography. Digging holes or pits is not an easy task in such dunes. In the eastern part, the ground is better for digging such holes. In spite of that, holes of 1.5 meter depth seems to be sometimes ineffective because of the ability of hares to jump and escape. In fact, the hind limbs of hare are relatively larger than those of rabbits and as a result, their ability to jump and escape will be greater (Boitani and Bartoli, 1983). Doubts about the use of greyhounds in rabbiting (i.e. tracking and catching Cape Hares) in the Gaza Strip still exist, because these dogs need great distances during their pursuit of hunting (Figure 6), and owning this kind of dogs is very expensive and may be difficult in light of the Israeli blockade imposed on the Gaza Strip since 2006. One possibility remains that some greyhounds may have been smuggled through the underground tunnels that connect the Gaza Strip to the Egyptian territories, to bring in many goods and animals, including zoo animals, livestock and perhaps greyhounds (Abd Rabou, 2009b; Butt and Butt, 2016).

Regardless to the means used in hunting Cape Hares, the process itself is considered difficult by hunters; especially in the Gaza Strip. They consider the animal a precious catch because of its rarity in the Gaza Strip. Urban encroachment at the expense of natural environment is a continuing process in the whole Gaza Strip; an area considered by global and local agencies as an ecologically and environmentally sensitive hot spot because of the Israeli occupation, blockade and security and military measures, the Israeli security and political fence separating it from the rest of Palestine, its small total area $\left(365 \mathrm{~km}^{2}\right)$ which equals $1.5 \%$ of Palestine, its overpopulation which exceeds 2.2 millions, its population density (5,500 people per square kilometer), resource depletion, habitat loss, environmental pollution and ecosystem fragility (Al-Agha, 1997; UNEP, 2003; Abd Rabou, 2009b; Abd Rabou and Abu Daher, 2009; Al-Najar et al., 2015; Safi, 2015 and Butt and Butt, 2016). The impact of the Israeli apartheid and segregation walls and fences on wildlife ecology and biodiversity flow was proved in the West Bank and the Gaza Strip (Abd Rabou, 2009a and Abdallah and Swaileh, 2011). In spite of this catastrophic environmental and political situation of the Gaza Strip, hunting of Cape Hares and other wildlife species; particularly birds near the eastern political fences of the Gaza Strip, which was made by Israel, is another real threat facing Gazan hunters as many of them have been killed or injured by the Israeli soldiers while practicing such hunting hobbies (Abd Rabou, 2005 and 2019a). 


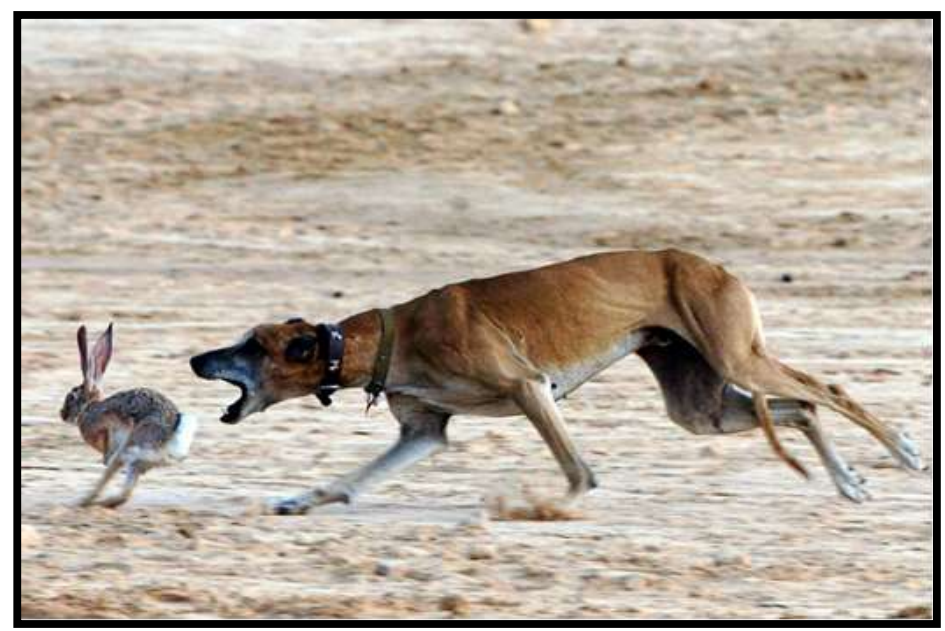

Figure 6 Rabbiting, which is the sport of hunting rabbits and hares, often needs great distances for greyhounds to track, chase and catch preys

The threats facing wildlife; especially the vertebrate fauna in the Gaza Strip have been touched on, or noted, in many local ecological and zoological studies. Habitat loss due to destruction, alteration, modification or deterioration is to be expected in an overpopulated area such as the Gaza Strip. For example, the extensive destruction of the wetland ecosystem of Wadi Gaza in the middle of the Gaza Strip and Al-Mawasi ecosystem in the south of Gaza Strip have negative impacts on wildlife ecology, including the ecology of Cape Hares. The sandy belt and the sand dune ecosystem characterizing the western region of the Gaza Strip have been extremely deteriorated because of urban encroachment, sand quarrying and accumulation of solid wastes of different categories; particularly the demolition wastes resulting from local developmental operations and the Israeli military wars and invasions. Habitat changes are thought to be the main cause of the decline in numbers of European Hares (Lepus europaeus) throughout Europe as revealed by Smith et al. (2004). In Jordan, Eid et al. (2020) pointed out that, despite the Cape Hare's widespread distribution, there has been a sharp decline in its population and its habitats are under continuous threats.

The Israeli and Palestinian use and application of chemical pesticides threaten wildlife as well. In the eastern belt of the Gaza Strip, the farmers plant wheat, barley, oat, melon, watermelon, carrot and low-growing, leafy vegetable crops, such as spinach, parsley, lettuce, rocket and chard. Some of these plants are major foods for the Cape Hare and other wild as well as domestic animals. The Israeli aerial spraying of chemical herbicides and germination inhibitors not only affects wildlife, it is also a flagrant violation of human rights as it destroys private property, destroys vital natural resources, and impedes sustainable development, while depriving thousands of people of their right to live. Abd Rabou and Al-Agha (1998) and Abd Rabou et al. (2002) demonstrated that pesticides were extensively used locally with no protective measures. In spite of their impacts on humans, pesticides present an alarming situation to wildlife and domestic animals (Abd Rabou, 1996). Of course, the Cape Hare which feeds on a variety of different plants could easily be poisoned. Abd Rabou (2020b) recorded secondary poisoning of Barn Owls (Tyto alba) in southern Gaza Strip as a result of the extensive use of pesticides. Overhunting of wildlife seems to be a crucial factor in threatening wildlife including Cape Hares. Hunting of various wildlife species may lead to the point that some species may reach advanced stages of threat, including extinction. Finally, the relative increase of some opportunist carnivores coming from the Palestinian Territories to the Gaza Strip may form a threat to the limited population of Cape Hares in the Gaza Strip. Such carnivores like jackals and foxes were known to feed on mammalian fauna as pointed out by various studies including local ones (Goszczyński and Wasilewski, 1992; Yom-Tov et al., 1995; Abd Rabou, 2009a; 2019a and c; 2021; Panek, 2009; Mohamed and Basuouny, 2016 and Zaman et al., 2020). In conclusion, the 
current study recommends the need to raise ecological awareness among Gazans; especially wildlife hunters to protect wildlife; particularly the Cape Hare in a sustainable fashion.

\section{Acknowledgement}

My thanks are due to Mr. Ahmad K. Jbareen and to Gazan wildlife hunters and farmers who supported the research with photos, valuable information, and qualitative discussions during the field and desk works of the current study.

\section{References}

Abdallah, T. and Swaileh, K. (2011): Effects of the Israeli Segregation Wall on biodiversity and environmental sustainable development in the West Bank, Palestine. International Journal of Environmental Studies, 68: 543-555.

Abd Rabou, A.N. (1996): On the hazards of pesticides use and misuse in Khartoum State, and some histopathological studies on the effects of carbamate insecticides on experimental animals. [M.Sc. Thesis], Institute of Environmental Studies (IES), University of Khartoum - Sudan, 78 $\mathrm{pp}$.

Abd Rabou, A.N. (2005): An ecological survey and assessment of Wadi Gaza Nature Reserve, Gaza Strip - Palestine, with particular emphasis on wildlife, [Ph.D. Thesis], Department of Environmental Studies, Faculty of Science and Technology, School of Life Sciences, Al-Neelain University - Sudan, $278 \mathrm{pp}$.

Abd Rabou, A.N. (2009a): On the occurrence of some carnivores in the Gaza Strip, Palestine (Mammalia: Carnivora). Zoology in the Middle East, 46: 109-112.

Abd Rabou, A.N. (2009b): The Zionist siege and its environmental consequences in the Gaza Strip. Palestine... 61 years after Nakba, May 16-17, 2009, Faculty of Arts, Islamic University of Gaza, 911-933.

Abd Rabou, A.N. (2011a): On the ecology of Wadi Gaza, Gaza Strip: Survey and assessment (Wildlife is focused). LAP Lambert Academic Publishing, Germany, 304 pp.

Abd Rabou, A.N. (2011b): The Palestinian mammalian fauna acquired by the zoological gardens in the Gaza Strip. Nusantara Bioscience, 3(2): 92-101 .

Abd Rabou, A.N. (2019a): The mammalian, reptilian and amphibian fauna of Al-Mawasi ecosystem, south-western Gaza Strip - Palestine. Agricultural Research \& Technology: Open Access Journal, 23(1): 00301-00314.

Abd Rabou A.N. (2019b): Threats facing the archaeological sites and buildings in the Gaza Strip, Palestine. The 4th International Conference on Rehabilitation of Historic Sites and Buildings within the Modern Requirements, IWAN Center for Cultural Heritage and Department of Architecture, Faculty of Engineering, Islamic University of Gaza, April 23-24, 2019, 1-30.

Abd Rabou, A.N. (2019c): On the occurrence, ecology and risks of the Egyptian Mongoose (Herpestes ichneumon Linnaeus, 1758) in the Gaza Strip - Palestine. Agricultural Research \& Technology: Open Access Journal, 23(2): 00267- 00276.

Abd Rabou, A.N. (2020a): The Palestinian marine and terrestrial vertebrate fauna preserved at the Biology Exhibition, Islamic University of Gaza, bombarded by the Israeli Army in December, 2008. Israa University Journal of Applied Science (IUGAS), 4(1): 9-51.

Abd Rabou, A.N. (2020b): On the owls (Order Strigiformes) inhabiting the Gaza Strip - Palestine: Mini Review. JOJ Wildlife \& Biodiversity, 3(1): JOJWB.MS.ID.555603.

Abd Rabou, A.N. (2020c): How is the COVID-19 outbreak affecting wildlife around the world? Open Journal of Ecology (OJE), 10(8): 497-517.

Abd Rabou, A.N. and Abu Daher, K.S. (2009): The environmental tragedy of Wadi Gaza after 60 years on the Palestine Nakba. Palestine... 61 years after Nakba, May 16-17, 2009, Faculty of Arts, Islamic University of Gaza, 935- 954. 
Abd Rabou, A.N. and Al-Agha, M.R. (1998): Environmental awareness in handling and application of pesticides in Rafah Governorate - Gaza Strip, The 5th International HCH and Pesticides Forum, Bilbao, Spain, June 25-27, 1998, 313-323.

Abd Rabou, A.N.; Baroud, N.S. and Yassin, M.M. (2002): Awareness of farmers towards pesticide use in the Gaza Strip. The Egyptian Journal of Community Medicine. 20(2): 59-71.

Abd Rabou, A.N.; Elkahlout, K.E.; Almabhouh, F.A.; Mohamed, W.F.; Khalaf, N.A.; Al-Sadek, M.A.; Alfarra, R.N.; Al-Moqayed, L.T.; Shafei, A.A.; Fayyad, N.A.; Adeem, B.S.; Dardona, A.W.; Al-Agha, M.R. and Abd Rabou, M.A. (2021): Occurrence and some ecological aspects of the Golden Jackal (Canis aureus Linnaeus, 1758) in the Gaza Strip, Palestine. Open Journal of Ecology (OJE), 11(2):

Abd Rabou, A.N.; Musallam, N.J.; Musallam, E.J.; Elkahlout, K.E.; Elnabris, K.J.; El-Bashiti, T.A.; Abdel Aziz, I.I; Ishneiwra, R.M.; Radwan, E.S.; Saada, H.S.; Shafei, A.A.; Fayyad, N.A.; Mwafy, S.N.; Abu Amra, H.E.; Abu Al-Ajeen, R.A.; Abu Owda, M.F.; Alfarra, R.N.; Hassouna, H.A.; Hassouna, R.A.; Al-Agha, M.R. and Abd Rabou, M.A. (2020): The Palestinian terrestrial vertebrate fauna preserved at the biology exhibitions of the universities of the Gaza Strip. Research in Ecology, 2(4): 9-21.

Abd Rabou, A.N.; Yassin, M.M.; Al-Agha, M.R.; Hamad, D.M. and Ali, A.S. (2007): Wild mammals in the Gaza Strip, with particular reference to Wadi Gaza. The Islamic University Journal (Series of Natural Studies and Engineering), 15(1): 87-109.

Al-Agha, M.R. (1997): Environmental management in the Gaza Strip. Environmental Impact Assessment Reviews, 17: 65-76.

Albaba, I. (2016): The terrestrial mammals of Palestine: A preliminary checklist. International Journal of Fauna and Biological Studies, 3(4): 28-35 .

Albaba, I. (2017): Surveying wildlife roadkills in the West Bank Governorates - Palestine, Journal of Entomology and Zoology Studies, 5(4): 910-913 .

Al-Jumaily, M.M. (1998): Review of the mammals of the Republic of Yemen. Fauna of Saudi Arabia, 17: 477-502.

Al-Najar, H.; Al-Rayes, N.; Dokhan, A.; Saqer, A.; Silmi, R. and Al-Kurdi, S. (2015): Assessing heavy metals pollution in the agricultural lands of Gaza Strip that has undergone three executive wars. American Journal of Environmental Protection, 3(4): 151-158.

Aloufi, A. and Eid, E. (2016): Zootherapy: A study from the Northwestern region of the Kingdom of Saudi Arabia and the Hashemite Kingdom of Jordan. Indian Journal of Traditional Knowledge, 15: 561-569.

Al-Sheikhly, O.F.; Haba, M.K.; Barbanera, F.; Csorba, G. and Harrison, D.L. (2015): Checklist of the mammals of Iraq (Chordata: Mammalia). Bonn Zoological Bulletin, 64 (1): 33-58

Amr, Z.S. (2000): Jordan country study on biological diversity: Mammals of Jordan. United Nations Environment Program (UNEP), Amman, $100 \mathrm{pp}$.

Amr, Z.S. (2012): Mammals of Jordan, 2nd Edition. Al Rai Press, Amman, Jordan, 308 pp.

Amr, Z.S.; Abu Baker, M.A. and Rifai, L. (2004): Mammals of Jordan. Denisia, 14(2): 437-465.

Amr, Z.S. and Disi, A. (1988): Jordanian mammals acquired by the Jordan University Natural History Museum. Publication of the University of Jordan, Amman, $32 \mathrm{pp}$.

Amr, Z.S.; Woodburry, S. and Disi, A.M. (1987): On a collection of mammals from Jordan. Dirasat, 14: 131-136.

Anabtawi, R. (2011): The people of Al-Kafriyat miss the Cape Hare and the Partridge as part of their beautiful childhood memories. Afaq for Environment and Development: A monthly electronic magazine issued by MA'AN Development Center, No. 36, https://www.maanctr.org/magazine/Archive/Issue36/topic8.-php.

Basuony, M.I. (1998): Feeding ecology of mammalian assemblages of Sinai, Egypt. Proceedings of the Egyptian Academy of Sciences, 48: 271-286.

Ben Slimen, H.; Suchentrunk, F.; Memmi, A. and Ben Ammar Elgaaied, A. (2005): Biochemical genetic relationships among Tunisian Hares (Lepus sp.), South African Cape Hares (L. capensis), and European Hares (L. europaeus). Biochemical Genetics, 43(11/12:( 
Ben Slimen, H.; Suchentrunk, F. and Elgaaied, A.B.A. (2008a): On shortcomings of using mtDNA sequence divergence for the systematics of hares (genus Lepus): an example from Cape Hares. Mammalian Biology, 73(1): 25-32.

Ben Slimen, H.; Suchentrunk, F.; Stamatis, C.; Mamuris, Z.; Sert, H.; Alves, P.; Kryger, U.; Shahin, A. and Benammarelgaaied, A. (2008b): Population genetics of Cape and Brown Hares (Lepus capensis and L. europaeus): A test of Petter's theory of conspecificity. Biochemical Systematics and Ecology, 36(1): 22-39.

Boitani, L. and Bartoli, S. (1983): Simon and Schuster's guide to mammals. Simon and Schuster Inc., $511 \mathrm{pp}$.

Borkowski, J.; Zalewski, A. and Manor, R. (2011): Diet composition of Golden Jackals in Israel. Annales Zoologici Fennici, 48(2): 108-118.

Brooks, J.E.; Ahmad, E. and Hussain, I. (1988): Characteristics of damage by vertebrate pests to groundnut in Pakistan. Vertebrate. Pest Conference, 1-3 March, 1988, Montery, California, pp. 129-33.

Bsissa, H.B.; Ashour, M.F. and Jdeidi, T.B. (2019): Wild mammals in northwestern Libya and the role of rain and temperature in its geographical distribution. The Libyan Journal of Science (An International Journal): 22: 27-44 .

Bunaian, F.; Hatough, A.; Ababaneh, D.; Mashaqbeh, S.; Yuosef, M. and Amr, Z.S. (2002): The carnivores of the northeastern Badia, Jordan. Turkish Journal of Zoology, 25: 19-25.

Butt, K.M. and Butt, A.A. (2016): Blockade on Gaza Strip: A living hell on Earth. Journal of Political Studies, 23(1): 157-182.

Chammem, M.; Karssene, Y.; Mohsen, J. and Khorchani, T. (2017): Estimating Cape Hare occupancy and abundance in southern Tunisia using spotlighting data. African Zoology, 52(3): 137-146.

De Marinis, A. and Masseti, M. (2009): Mammalian fauna of the Termessos National Park, Turkey. ZooKeys, 31: 221-228.

Demirbaş, Y.; Albayrak, I. and Yilmaz, A. (2013): Studies of ecomorphological variations of the European hare (Lepus europaeus) in Turkey. Archives of Biological Sciences, 65(2): 559-566.

Djan, M.; Stefanovic, M.; Velickovic1, N.; Lavadinovic, V.; Alves, P.C. and Suchentrunk, F. (2017): Brown hares (Lepus europaeus Pallas, 1778) from the Balkans: A refined phylogeographic model. Hystrix, the Italian Journal of Mammalogy, 28(2): 186-193.

Dolev, A. and Perevolotsky, A. (2005): The Red Book: Vertebrates in Israel. Israel Nature and Parks Authority, Society for the Protection of Nature in Israel, $318 \mathrm{pp}$.

Drew, C. (2000): The distribution of the Cape Hare (Lepus capensis) in Abu Dhabi Emirate, United Arab Emirates, Zoology in the Middle East, 20(1): 15-20.

Edwards, P.J.; Fletcher, M.R. and Berny, P. (2000): Review of the factors affecting the decline of the European Brown Hare, Lepus europaeus (Pallas, 1778) and the use of wildlife incident data to evaluate the significance of paraquat. Agriculture, Ecosystems \& Environment, 79: 95-103.

Edwards, S., Al Awaji, M., Eid, E., and Attum, O. (2017): Mammalian activity at artificial water sources in Dana Biosphere Reserve, southern Jordan. Journal of Arid Environments, 2: 141. https://doi.org/10.1016/j. jaridenv.2017.01.015

Eid, E. (2018): A hunter's guide in the Hashemite Kingdom of Jordan. The Royal Society for the Conservation of Nature (RSCN), Amman, Jordan, 156 pp.

Eid, E. and Handal, R. (2018): Illegal hunting in Jordan: Using social media to assess impacts on wildlife. Oryx, 52(4): 730-735.

Eid, E.; Abu Baker, M. and Amr, Z. (2020): National Red data book of mammals in Jordan. International Union for Conservation of Nature and Natural Resources, IUCN Regional Office for West Asia, Amman, Jordan, 122 pp.

Eid, E.; Al Hasani, I.; Al Share, T.; Abed, O. and Amr, Z. (2010): Animal trade in Amman local market, Jordan. Jordan Journal of Biological Science, 4(2): 101-108.

Elhalawani, S. (2016): Hunting and illegal killing of birds along the Mediterranean coast of Egypt: Socioeconomic study. Report by Nature Conservation Egypt \& BirdLife International, 42 pp . 
Elkahwage, I.E. and Jdeidi, T.B. (2018): Survey of the wild mammalian species in Misallatah Nature Reserve and National Park (MNRNP). Attie Memorie Dell'ente Fauna Siciliana, XII, 101-112.

Erasmus, S.W. and Hoffman, L.C. (2020): Putting the spring back into the Hare (Pedetes capensis): Meat chemical composition of an underutilized protein source. Foods, 9 (1096): 1-15, doi: 10.3390/foods9081096.

Essghaier, M.F.; Taboni, I.M. and Etayeb, K.S. (2015): The diversity of wild animals at Fezzan Province, Libya. Biodiversity Journal, 6(1): 245-252.

Fargher, S.E. (1977): The distribution of the Brown Hare (Lepus capensis) and the Mountain Hare (Lepus timidus) in the Isle of Man. Journal of Zoology - London, 182(2): 164-167.

Goszczyński, J. and Wasilewski, M. (1992): Predation of Red Foxes on a hare population in central Poland. Acta theriologica, 37(4): 329-338.

Flux, J.E. and Flux, M.M. (1983): Taxonomy and distribution of East African Hares. Acta Zoologica Fennica, 174: 41-43.

Haltenorth, T. and Diller, H. (1996): Mammals of Africa including Madagascar. Harper Collins, London. 403 pp.

Harrison, D.L. and Bates, P.J.J. (1991): The mammals of Arabia. Harrison Zoological Museum, Kent, England, $354 \mathrm{pp}$.

Hoath, R. (2003): A field guide to the mammals of Egypt. The American University in Cairo Press, Egypt, $234 \mathrm{pp}$.

Kamler, J.F. (2007): Ear flashing behavior of Cape Hares (Lepus capensis) in South Africa. African Journal of Ecology, 46: 443-444.

Kamler, J.F.; Jacobsen, N.F. and Macdonald, D.W. (2008): Efficiency and safety of Soft Catch traps for capturing Black-backed Jackals and excluding non-target species. South African Journal of Wildlife Research, 38(2): 113-116.

Khalaf, N.A. (1983): Order Lagomorpha in Palestine. Gazelle: The Palestinian Biological Bulletin, 1: 19.

King, C.M. (1990): The handbook of New Zealand mammals. Oxford University Press, Auckland. 600 pp.

Kronfeld, N. and Shkolnik, M. (1996): Adaptation to life in the desert in the Brown Hare (Lepus capensis). Journal of Mammalogy, 77(1): 171-178.

Lado, S.; Alves, P.C.; Islam, M.Z.; Brito, J.C. and Melo-Ferreira, J. (2019): The evolutionary history of the Cape Hare (Lepus capensis sensu lato): Insights for systematics and biogeography. Heredity (Edinb), 23(5): 634-646.

MedWetCoast (2002): Management plan: Wadi Gaza. Project for the Conservation of Wetland and Coastal Ecosystems in the Mediterranean Region - MedWetCoast, $171 \mathrm{pp}$.

Meiri, S.; Belmaker, A.; Berkowic, D.; Kazes, K.; Maza, E.; Bar-Oz, G. and Dor, R. (2019): A checklist of Israeli land vertebrates. Israel Journal of Ecology and Evolution, 65(1-2): 43-70.

Mendelssohn, H. (1972): Ecological effects of chemical control of rodents and jackals in Israel. In: Favar, T.M. and Milton, J.P. (eds.): The Careless Technology: Ecology and International Development. Natural History, New York, pp 527-544.

Mohamed W. F. and Basuony, M. I. (2016): Food composition and feeding ecology of the Arabian Red Fox Vulpes vulpes arabica (Thomas, 1902) in Sakaka, northern Saudi Arabia. Journal of Bioscience and Applied Research, 2(11): 723-728.

Mohammed, F.M.; Hashim, I.M. and Ibrahim, M.T. (2016): Skull morphometric of hares collected from three geographic regions in Sudan. International Journal of Current Microbiology and Applied Sciences, 5(9): 380-389.

Mohsen, C.; Yamna, K.; Mohsen, J. and Touhami, K. (2017): Estimating Cape Hare occupancy and abundance in southern Tunisia using spotlighting data. African Zoology, 52(3): 137-146.

Moores, R.; Brown, D.; Martin, R. and Lees, A.C. (2012): Status and identification of hares Lepus sp. in Western Sahara and Southern Morocco. Go-South Bulletin, 9: 126-130.

Moran, S. (1981): Damage by vertebrates to plastic irrigation pipes in Israel. Phytoparasitica, 9: 211216. 
Moran, S. (2003): Checklist of vertebrate damage to agriculture in Israel, updated for 1993-2001. Phytoparasitica, 31(2):109-117.

Moran, S. and Keidar, H. (1993): Checklist of vertebrate damage to agriculture in Israel. Crop Protection, 12:173-182.

Nader, M.R.; El-Indary, S.; Abi Salloum, B. and Abou Dagher, M. (2011): Combining non-invasive methods for the rapid assessment of mammalian richness in a transectquadrat survey scheme - Case Study of the Horsh Ehden Nature Reserve, North Lebanon. ZooKeys, 119: 63-71.

Oğurlu I. (1997): Habitat use and food habits of Brown Hare (Lepus europaeus Pallas) in a woodland. Turkish Journal of Zoology, 21: 381-398.

Panek, M. (2009): Factors affecting predation of Red Foxes (Vulpes vulpes) on Brown Hares (Lepus europaeus) during the breeding season in Poland. Wildlife Biology, 15(3): 345-349 .

Panek, M.; Kamieniarz, R. and Bresinski, W. (2006): The effect of experimental removal of Red Foxes Vulpes vulpes on spring density of Brown Hares Lepus europaeus in western Poland. Acta Theriologica, 51: 187-193 .

Paray, B.A. and Al-Sadoon, M.K. (2018): A survey of mammal diversity in the Turaif province, Kingdom of Saudi Arabia. Saudi Journal of Biological Sciences, 25(3): 604-608.

Phillips, R.; Gruver, K. and Williams, E. (1996): Leg injuries to coyotes captured in three types of foothold traps. Wildlife Society Bulletin, 24(2): 260-263.

Qumsiyeh M.B. (1996): Mammals of the Holy Land. Texas Tech. University Press, U.S.A., 389 pp .

Qumsiyeh, M.B. (2016): Fauna of Wadi Al-Quff Protected Area: Amphibians, reptiles and mammals. Jordan Journal of Natural History, 3: 70-79.

Qumsiyeh, M.B.; Khalilieh, A.; Albaradeiyab, I.M. and Al-Shaikh, B. (2016): Biodiversity conservation of Wadi Al-Quff protected area (central Palestine): Challenges and opportunities. Jordan Journal of Natural History (JJNH), 3: 6-24 .

Qumsiyeh, M.; Zavala, S. and Amr, Z. (2014): Decline in vertebrate biodiversity in Bethlehem area (occupied Palestinian Territories). Jordan Journal of Biological Sciences, 7(2): 101-107.

Reichlin, T.; Klansek, E. and Hackländer, K. (2006): Diet selection by hares (Lepus europaeus) in arable land and its implications for habitat management. European Journal of Wildlife Research, 52(2): 109-118.

Robinson, T.J. and Dippenaar, N.J. (1983): The status of Lepus saxatilis, L. whytei and L. crawshayi in southern Africa. Acta Zoologica Fennica, 174, 35-39.

Safi, A.S. (2015): 2014 War on Gaza Strip: Participatory environmental impact assessment. Palestinian Environmental NGOs Network - FoE Palestine, MA'AN Development Center, 78 pp.

Schai-Braun, S.C.; Kowalczyk, C.; Klansek, E. and Hackländer, K. (2019): Estimating sustainable harvest rates for European Hare (Lepus Europaeus) populations. Sustainability, 11(2837): 120, doi: $10.3390 /$ su11102837.

Seddon, P.J.; van Heezik, Y. and Nader, I.A. (1997): Mammals of the Harrat al-Harrah Protected Area, Saudi Arabia. Zoology in the Middle East, 14(1):37-46.

Sert, H.; Suchentrunk, F.; Erdogan, A. (2005): Genetic diversity in brown hares (Lepus europaeus Pallas, 1778) from Anatolia and differentiation among Anatolian and European populations. Mammalian Biology, 70: 171-186.

Shilereyo, M.; Magige, F.J.; Ogutu, J.O. and Røskaft, E. (2020): Small mammal community demography and reproductive seasonality under protection, pastoralism and agriculture in the Serengeti Ecosystem, Tanzania. International Journal of Biodiversity and Conservation, 12(4): 253-269.

Sliwinski, K.; Ronnenberg, K.; Jung, K.; Strauß, E. and Siebert, U. (2019): Habitat requirements of the European Brown Hare (Lepus europaeus PALLAS 1778) in an intensively used agriculture region (Lower Saxony, Germany). BMC Ecology, 19(31): 1-11, https://doi.org/10.1186/s12898-019-0247-7.

Smith, R.; Jennings, N.; Robinson, A. and Harris, S. (2004): Conservation of European Hares (Lepus europaeus) in Britain: Is increasing habitat heterogeneity in farmland the answer? Journal of Applied Ecology, 41(6): 1092-1102. 
Strevens, T. and Rochford, J. (2004): The diet and impact of the Irish Hare (Lepus timidus hibernicus, Bell 1837) in a young plantation. Biology and Environment: Proceedings of the Royal Irish Academy, 104B(2): 89-94.

Suchentrunk, F.; Alkon, P.U.; Willing, R. and Yom-Tov, Y. (2006): Epigenetic dental variability of Israeli hares (Lepus sp.): Ecogenetic or phylogenetic causation? Journal of Zoology, 252(4): 503-515.

Suchentrunk, F.; Flux, J.E.C.; Flux, M.M. and Ben Slimen, H. (2007): Multivariate discrimination between East African Cape Hares (Lepus capensis) and Savanna Hares (L. victoriae) based on occipital bone shape. Mammalian Biology, 72: 372-383 .

Tapper, S.C. and Barnes, R.F.W. (1986): Influence of farming practice on the ecology of the Brown Hare (Lepus europaeus). Journal of Applied Ecology, 23: 39-52.

UNEP (2003): Desk study on the environment in the Occupied Palestinian Territories. United Nations Environment Program (UNEP), Nairobi, Kenya, $188 \mathrm{pp}$.

Wilson, D.E. and Reeder, D.M. (2005): Mammal species of the world: A taxonomic and geographic reference. 3rd edition, John Hopkins University Press, Baltimore. 2142 pp .

Yassin, M.M.; Abd Rabou, A.N. and Al-Agha, M.R. (2006): Preliminary survey of terrestrial vertebrate fauna and people's awareness towards wildlife in the Northern Governorate of the Gaza Strip. Al-Azhar Bulletin of Science: Zoology \& Botany, 17(1): 17-41 .

Yom-Tov, Y. (2003): Poaching of Israeli wildlife by guest workers. Biological Conservation, 110: 1120.

Yom-Tov, Y.; Ashkenazi, S. and Viner, O. (1995): Cattle predation by the Golden Jackal Canis aureus in the Golan Heights, Israel. Biological Conservation, 73: 19-22.

Yom-Tov, Y. and Yom-Tov, S. (2012): Observations on variation in skull size of three mammals in Israel during the 20th century. Zoologischer Anzeiger, 251: 331-334 .

Yusefi, G.H.; Faizolahi, K.; Darvish, J.; Safi, K. and Brito, J.C. (2019): The species diversity, distribution, and conservation status of the terrestrial mammals of Iran, Journal of Mammalogy, 100(1): 5571.

Zaman, M.; Rakha, B.A.; Bao, H.; Vitekere, K. and Jiang, G. (2020): Effect of habitat factors and predator density on the spatial abundance of Cape Hare (Lepus capensis) in the Karakorum Range. Applied Ecology and Environmental Research, 18(2): 2921-2934.

Zellweger-Fischer, J.; Kéry, M. and Pasinelli, G. (2011): Population trends of Brown Hares in Switzerland: The role of land-use and ecological compensation areas. Biological Conservation, 144(5): 1364-1373. 